University of Nebraska - Lincoln

DigitalCommons@University of Nebraska - Lincoln

Faculty Publications: Department of Entomology

September 1988

\title{
Geographical Variation in Responses to Photoperiod and Temperature by Leptinotarsa decemlineata (Coleoptera: Chrysomelidae) During and After Dormancy
}

\author{
Maurice J. Tauber \\ Cornell University \\ Catherine A. Tauber \\ Cornell University \\ John J. Obrycki \\ Cornell University \\ Brian Gollands \\ Cornell University \\ Robert J. Wright \\ University of Nebraska-Lincoln, rwright2@unl.edu
}

Follow this and additional works at: https://digitalcommons.unl.edu/entomologyfacpub

Part of the Entomology Commons

Tauber, Maurice J.; Tauber, Catherine A.; Obrycki, John J.; Gollands, Brian; and Wright, Robert J., "Geographical Variation in Responses to Photoperiod and Temperature by Leptinotarsa decemlineata (Coleoptera: Chrysomelidae) During and After Dormancy" (1988). Faculty Publications: Department of Entomology. 100.

https://digitalcommons.unl.edu/entomologyfacpub/100

This Article is brought to you for free and open access by the Entomology, Department of at DigitalCommons@University of Nebraska - Lincoln. It has been accepted for inclusion in Faculty Publications: Department of Entomology by an authorized administrator of DigitalCommons@University of Nebraska - Lincoln. 


\title{
Geographical Variation in Responses to Photoperiod and Temperature by Leptinotarsa decemlineata (Coleoptera: Chrysomelidae) During and After Dormancy
}

\author{
MAURICE J. TAUBER, CATHERINE A. TAUBER, JOHN J. OBRYCKI, ${ }^{1}$ \\ BRIAN GOLLANDS, AND ROBERT J. WRIGHT ${ }^{2}$
}

\author{
Department of Entomology, Comstock Hall, Cornell University, \\ Ithaca, New York 14853
}

\begin{abstract}
Ann. Entomol. Soc. Am. 81(5): 764-773 (1988)
ABSTRACT The intensity of diapause has a distinct seasonal pattern in the Colorado potato beetle, Leptinotarsa decemlineata (Say). During August, temperature and photoperiod only slightly affected the very intense diapause in field populations. By summer's end, diapause intensity diminishes, but photoperiod and temperature maintain diapause. Subsequently, the beetles lose their responsiveness to photoperiod at high temperatures (approximately $20^{\circ} \mathrm{C}$ ), but at low temperatures $\left(18-15^{\circ} \mathrm{C}\right)$ the beetles remain photoperiodically sensitive after emerging from the soil and initiating oviposition in the spring. Mated females that overwinter can lay fertile eggs without mating in the spring. Populations from climatically different areas in New York state (Riverhead, Long Island and Freeville, Upstate New York) have similar thermal thresholds (approximately $12^{\circ} \mathrm{C}$ ) for reproductive development after dormancy. However, the Riverhead population has a less intense diapause and lower thermal requirements for initiating oviposition ( $K=135 \mathrm{HDD}_{12}$ [heat-degree days]) than the Freeville population $\left(K=213 \mathrm{HDD}_{12}\right)$. This diversity results in large differences in the timing of vernal emergence and oviposition at the two sites. The results suggest that natural selection acts on both the timing of emergence and oviposition after dormancy and on the variation in the occurrence of the events.
\end{abstract}

KEY WORDS Insecta, diapause termination, phenology, photoperiod

EVOLUTIONARY ANALYSES of life histories generally are undertaken from demographic or genetic viewpoints; seldom do they include physiological considerations. However, physiological processes are the vital connection between the ecological expression of life history traits that determine fitness, and the components of population genetics that constitute heritability and genetic covariances (Stearns 1983, Tauber \& Tauber 1986). When physiological aspects are neglected, life history studies offer an incomplete and static view of the dynamic interactions between populations, organisms, and the environment.

Seasonality is a primary environmental variable that influences the expression of life history traits. The environmental cues that regulate reproduction, development, migration, and dormancy, and the physiological responses to these cues change with seasons. Thus, comparative studies of the ecophysiological interactions between organisms and their seasonal environments give a vital dimension to the understanding of evolutionary processes.

The Colorado potato beetle, Leptinotarsa decemlineata (Say), is an excellent subject for ecophysiological investigations of how life histories

\footnotetext{
' Current address: Department of Entomology, Iowa State University, Ames, Iowa 50011.

${ }^{2}$ Current address: Department of Entomology, University of Nebraska, Lincoln, Nebr. 68583.
}

evolve. The seasonal cycle of the species is well studied; skillful workers have clarified the physiological and endocrine bases for many of its life history functions (e.g., de Kort et al. 1980, de Kort 1981, Briers et al. 1982). Much of the physiological work with the Colorado potato beetle has been undertaken with a strong ecological perspective (see Arnoldi 1966, de Kort et al. 1980, de Wilde \& Hsiao 1981, Hsiao 1981).

Our paper focuses on the physiological interface between ecology and genetics by evaluating interpopulation and intrapopulation differences in the seasonal responses to the factors that regulate dormancy and oviposition in the field. Our study involved two populations of $L$. decemlineata-one from Upstate New York (Freeville, Tompkins County; latitude: $42^{\circ} 27^{\prime} \mathrm{N}$ ) and one from Long Island, New York (Riverhead, Suffolk County; latitude: $40^{\circ} 58^{\prime} \mathrm{N}$ ). The upstate locality is about 300 $\mathrm{km}$ inland from the one on Long Island. Upstate, the climate is cooler, the soils are heavier (Rhineland silt loam, as opposed to sandy loam on Riverhead), and the growing season is shorter than on Long Island. The population of Colorado potato beetle at Freeville is mostly univoltine, with some bivoltinism; on Long Island, however, a large portion of the population produces a second generation (M. J. Tauber et al. 1988).

We asked the following questions: What is the seasonal pattern of response to diapause-maintain- 
ing stimuli? What is the intrapopulation and interpopulation variation in the ecophysiological status of beetles during diapause? What variability in responses underlies reproductive development leading to emergence and reproduction by overwintered beetles?

\section{Materials and Methods}

Once induced, dormancy typically is divided into two physiologically distinct periods: diapause maintenance (during which token stimuli act to prevent development and reproduction, even if environmental conditions are favorable) and postdiapause development (during which favorable conditions promote developmental and reproductive processes) (Tauber et al. 1986). Because these physiological states are not easily recognized in living beetles, we used oviposition as a sign of diapause termination, therefore, our findings pertain largely to females. We defined the "preoviposition period" as the time (days) from field sample (or removal from cold conditions) to the initiation of oviposition; this period includes diapause development and postdiapause development.

In our tests, beetles were maintained in cages (0.24 liter) and continuously provided with bouquets of fresh Solanum tuberosum (cv. Katahdin) foliage. Temperatures fluctuated $\pm 0.5^{\circ} \mathrm{C}$ of the designated constant temperature. Reference specimens from each population are deposited in the Cornell University Insect Collection (Lot \# 1158).

Diapause Maintenance. We collected many adult $L$. decemlineata (second summer generation) at the end of summer and overwintered them in outdoor screen cages ( 75 by 60 by $90 \mathrm{~cm}$ ) that were dug into the soil to a depth of $30 \mathrm{~cm}$. Foliage from field-grown 'Katahdin' plants was provided until the beetles had burrowed into the soil.

At regular intervals from late summer through early spring, we transferred beetles from the field to a variety of photoperiodic and thermal conditions in the laboratory (Tables 1-4). The experiments were conducted over two years on the Freeville and the Riverhead populations, 1982-1983 and 1983-1984.

Postdormancy Reproduction. To determine the thermal requirements for reproduction after dormancy, we collected adults in mid (1983) or late (1982) summer (Freeville), or we reared and maintained adults under diapause-inducing conditions in the laboratory (Riverhead). After two weeks at $23.9^{\circ} \mathrm{C}$, the beetles were transferred through a series of decreasing temperatures $(21,18,16,10$, and $5^{\circ} \mathrm{C}$ ) at 2-wk intervals under a photoperiod of 10 : 14 (L:D). Beetles had continuous access to 'Katahdin' foliage until the temperature reached $5^{\circ} \mathrm{C}$. After approximately $3 \mathrm{mo}$ at $5^{\circ} \mathrm{C}$ (without food), paired adults were moved to a range of temperatures ( $\mathrm{Ta}$ ble 5) under a photoperiod of 10:14 or 16:8 and held to determine the preoviposition periods.
To find out if overwintered females must mate before ovipositing fertile eggs in spring, we ran two tests (Table 6). From the population at Freeville, we collected diapausing beetles in summer and overwintered them in the laboratory (as described above). When females were transferred from $5^{\circ} \mathrm{C}\left(10: 14\right.$ photoperiod) to $24^{\circ} \mathrm{C}(16: 8$ photoperiod), half were isolated in individual cages and half were paired with males. All received fresh potato foliage daily, and the incidence of fertile oviposition and the preoviposition periods were recorded. We conducted a similar test on the Riverhead population, except that beetles were overwintered under natural conditions. Females were transferred from the field to 21.1 or $24^{\circ} \mathrm{C}(16: 8$ photoperiod) in January and April 1984.

To analyze the relationship between temperature and development, we used the reciprocal of the developmental times (medians) and then fitted a regression line to the data from each population using the least-squares method. We estimated the lower thermal threshold, $t$, for each population by extrapolating the regression line through the $x$-axis (temperature). We then derived $K$ (heat-degree days, HDD) from the equation, $K=1 / y(x-t)$, in which $y=$ mean developmental rate and $x=$ temperature $\left({ }^{\circ} \mathrm{C}\right)$.

Postdormancy Emergence Under Field Conditions. In late summer, beetles were collected and placed into outdoor cages ( 180 by 180 by $180 \mathrm{~cm}$ ). They were provided field-grown 'Katahdin' foliage until they had burrowed into the soil. The cages were removed in late autumn and screened emergence traps were placed over the sites in early spring before emergence began. The traps were checked at least every two days. Soil temperatures were recorded from a depth of approximately 12 $\mathrm{cm}$ (Freeville) and $15 \mathrm{~cm}$ (Riverhead) (Table 7).

Ecophysiological Responses of Overwintered Beetles. To determine the responses of emerged beetles to diapause inducing conditions, we collected beetles that had overwintered under natural conditions at Freeville. The beetles were paired in cages ( 0.24 liter) and were continuously provided fresh 'Katahdin' foliage. In 1983, the beetles were exposed to a variety of temperatures under one photoperiod (16:8 photoperiod) (Table 8). In 1984, two temperatures and two photoperiods were tested (Table 8). For comparison, we examined the response of first-generation, summer beetles to long daylengths and high $\left(23.9^{\circ} \mathrm{C}\right)$ temperatures.

\section{Results}

Diapause Maintenance-Freeville (19821983 and 1983-1984). (Tables 1 and 2). In the sample from mid-August, diapause duration was similar across all photoperiods and temperatures; under all conditions the mean time to oviposition was greater than $140 \mathrm{~d}$. At all temperatures (especially the low temperatures), long daylength (16:8 


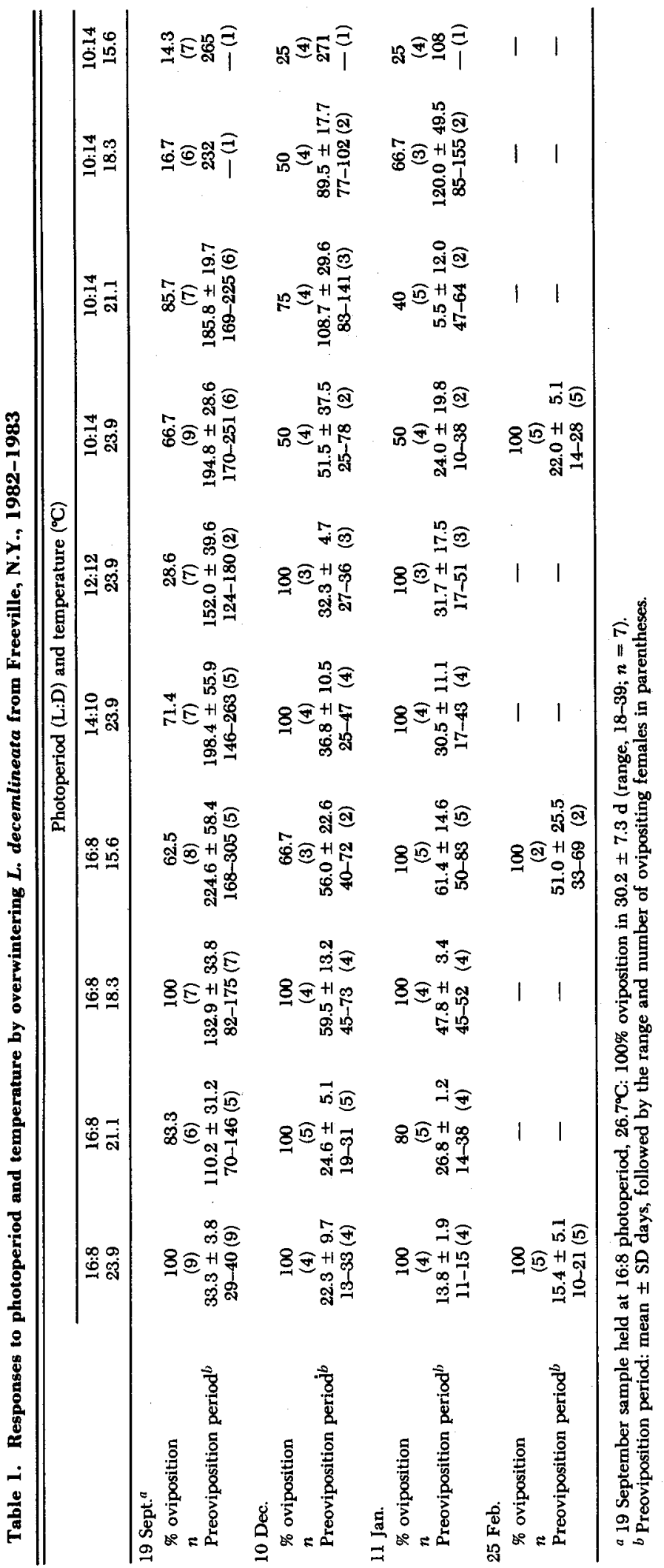




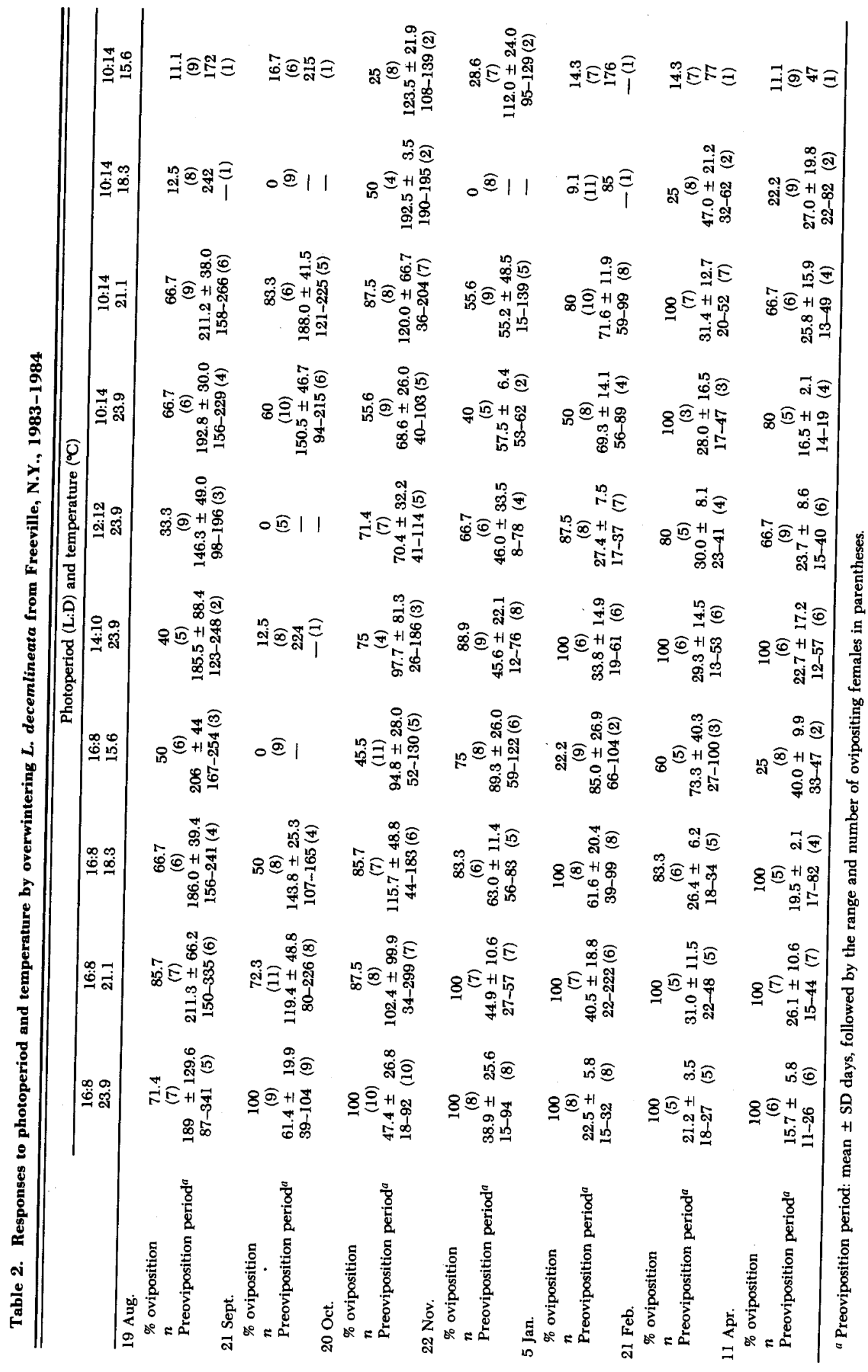


Vol. 81 , no. 5

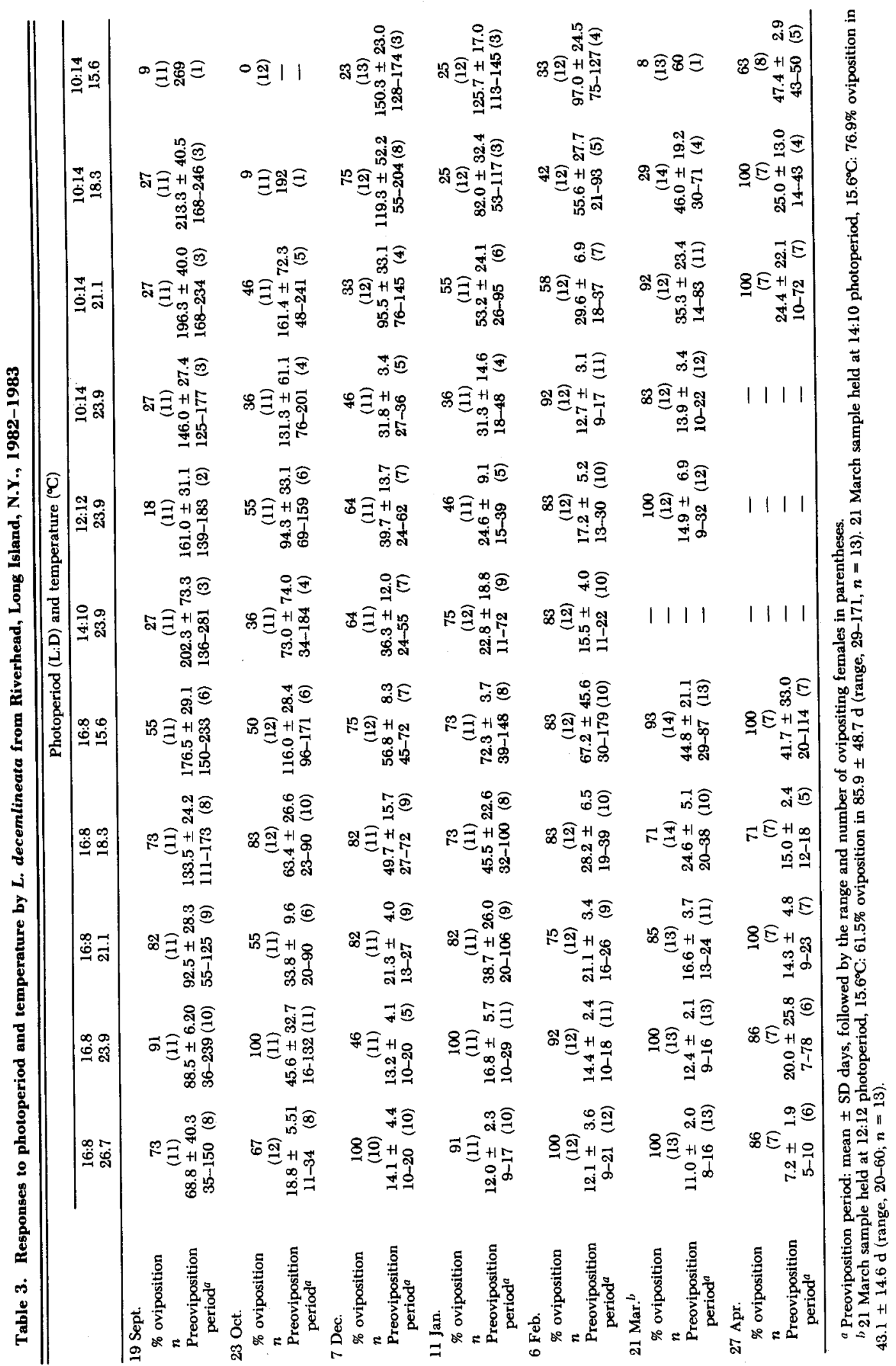


Table 4. Responses to photoperiod and temperature by overwintering $L$. decemlineata from Riverhead, Long Island, N.Y., 1983-1984

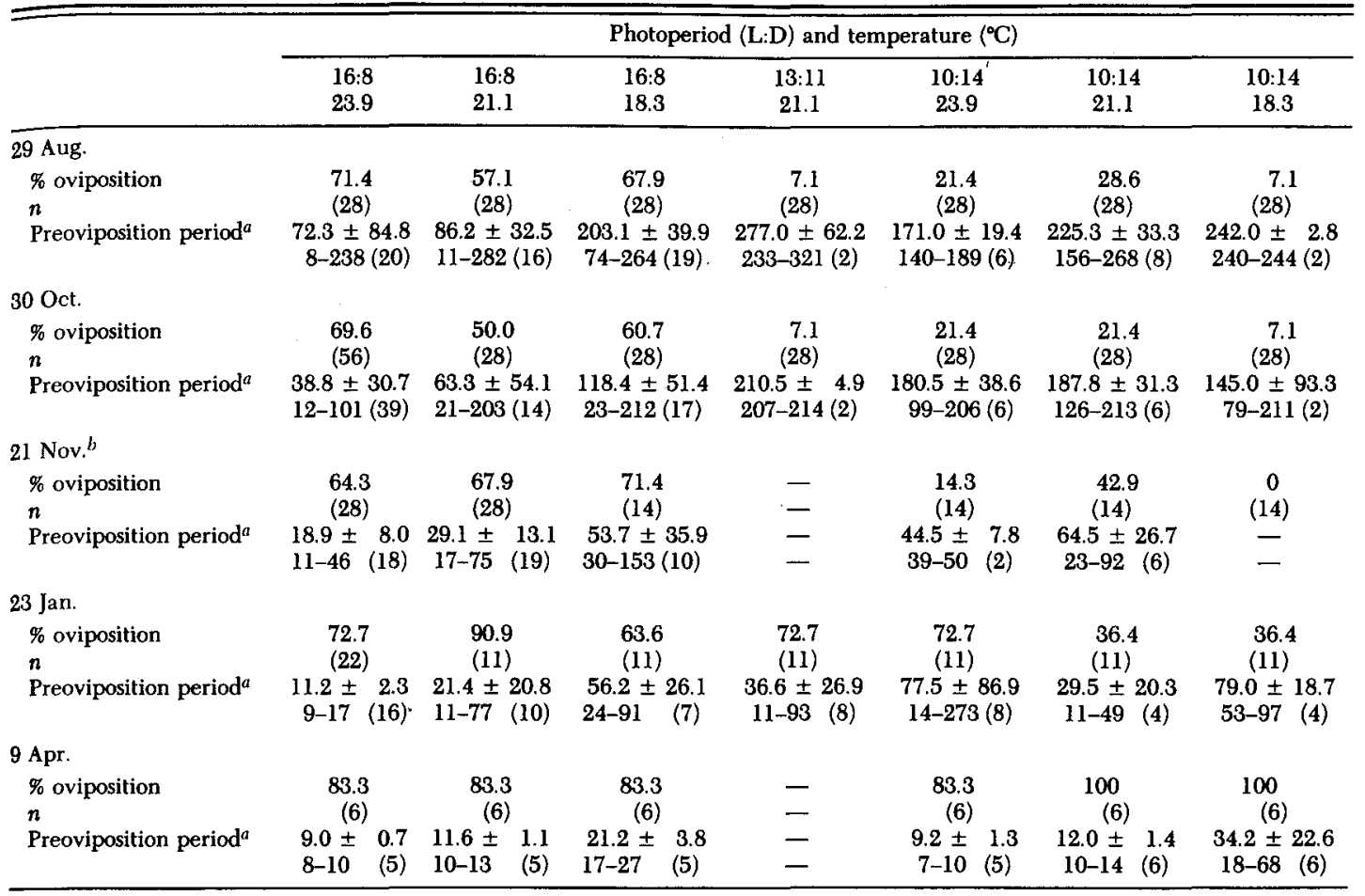

" Preoviposition period: mean \pm SD days, followed by the range and number of ovipositing females in parentheses.

b 21 November sample held at $14: 10$ photoperiod, $23.9^{\circ} \mathrm{C}$ yielded $71.4 \%$ oviposition $(n=14)$ in $18.5 \pm 5.3 \mathrm{~d}(\mathrm{range}, 7-24 ; n=10)$.

photoperiod) elicited a greater incidence of oviposition than did shorter daylengths (Table 2).

In September and October, a photoperiod of $16: 8\left(\right.$ at $23.9^{\circ} \mathrm{C}$ ) resulted in $100 \%$ reproduction, and at this temperature, oviposition occurred faster in 16:8 than in the other photoperiods (Tables 1 and 2). In most samples held at temperatures below $23.9^{\circ} \mathrm{C}$, the $16: 8$ photoperiod also increased the incidence of oviposition and shortened the preoviposition period.

In November, the $16: 8$ photoperiod at $21.1^{\circ} \mathrm{C}$ showed an increased incidence of oviposition and a decreased time to oviposition; photoperiods of 14:10 and 12:12 also showed a decrease in the preoviposition period. At temperatures below $23.9^{\circ} \mathrm{C}$, the incidence of oviposition was greater and the time to oviposition was shorter at long daylengths (16:8 photoperiod) than at short (10:14) ones.

By December and January $\left(\right.$ at $23.9^{\circ} \mathrm{C}$ ), the effect of daylength on the incidence of oviposition was diminished; only the samples held at short daylengths (12:12 photoperiod, January; 10:14 photoperiod, December and January) had less than $100 \%$ oviposition. At temperatures below $23.9^{\circ} \mathrm{C}$, photoperiod influenced the incidence of oviposition and the time to oviposition.

In February (at 23.9 and $21.1^{\circ} \mathrm{C}$ ), the incidence of oviposition was high and the preoviposition periods short under all photoperiods. Short daylengths continued to retard diapause development at 18.3 and $15.6^{\circ} \mathrm{C}$.

In the sample from April, short daylengths appeared to diminish the incidence of oviposition at 23.9 and $21.1^{\circ} \mathrm{C}$, but the time for first oviposition was not affected. The beetles held at 18.3 and $15.6^{\circ} \mathrm{C}$ remained sensitive to short daylengths.

Table 5. Geographical variation in thermal requirements for oviposition by $L$. decemlineata overwintered under low temperature $\left(5^{\circ} \mathrm{C}\right)^{a}$

\begin{tabular}{|c|c|c|c|}
\hline \multirow{2}{*}{$\begin{array}{l}\text { Temperature } \\
\left({ }^{\circ} \mathrm{C}\right)\end{array}$} & \multicolumn{2}{|c|}{ Preoviposition period (d) } & \multirow{2}{*}{ 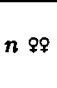 } \\
\hline & Mean $\pm S D$ & Range & \\
\hline \multicolumn{4}{|l|}{ Freeville, N.Y. } \\
\hline $\begin{array}{l}18.3 \\
21.0 \\
23.9 \\
26.7\end{array}$ & $\begin{array}{l}39.2 \pm 20.1 \\
29.6 \pm 14.5 \\
22.7 \pm 10.3 \\
15.2 \pm 3.9\end{array}$ & $\begin{array}{r}21-79 \\
14-79 \\
10-54 \\
9-23\end{array}$ & $\begin{array}{l}13 \\
25 \\
27 \\
19\end{array}$ \\
\hline \multicolumn{4}{|c|}{ Riverhead, Long Island, N.Y. } \\
\hline $\begin{array}{l}15.6 \\
18.3 \\
21.0 \\
23.9 \\
26.7\end{array}$ & $\begin{array}{l}38.1 \pm 14.4 \\
27.4 \pm 9.3 \\
20.3 \pm 12.5 \\
10.6 \pm 1.9 \\
16.8 \pm 15.4\end{array}$ & $\begin{array}{r}28-70 \\
16-40 \\
10-64 \\
7-13 \\
7-46\end{array}$ & $\begin{array}{r}8 \\
5 \\
20 \\
7 \\
6\end{array}$ \\
\hline
\end{tabular}

a Results at 10:14 and 16:8 photoperiod did not differ significantly; therefore when both photoperiods were tested (Freeville: 21.0 and $23.9^{\circ} \mathrm{C}$; Riverhead: $21.0^{\circ} \mathrm{C}$ ), both sets of data are included. All other data points are from 16:8 photoperiod. 
Table 6. Influence of males on fertile oviposition by field-collected $L$. decemlineata females after overwintering under laboratory $\left(5^{\circ} \mathrm{C}\right)$ or natural conditions

\begin{tabular}{|c|c|c|c|c|}
\hline & \multicolumn{2}{|c|}{ Unpaired $9 \%$} & \multicolumn{2}{|c|}{89 with 88} \\
\hline & $\begin{array}{c}\% \text { fertile } \\
\text { oviposition }(n)\end{array}$ & $\begin{array}{l}\text { Preoviposition } \\
\text { period }^{a}\end{array}$ & $\begin{array}{c}\% \text { fertile } \\
\text { oviposition }(n)\end{array}$ & $\begin{array}{l}\text { Preoviposition } \\
\text { period }^{a}\end{array}$ \\
\hline \multicolumn{5}{|l|}{ Freeville, N.Y. } \\
\hline $\begin{array}{l}\text { Collected in summer and overwintered } \\
\text { in laboratory; tested in April }\end{array}$ & $86(7)$ & $\underset{(6)}{17.7 \pm 7.1}$ & $100(13)$ & $\begin{array}{c}25.1 \pm 11.6 \\
(13)\end{array}$ \\
\hline \multicolumn{5}{|l|}{ Riverhead, N.Y. } \\
\hline Collected and tested in January; $21.1^{\circ} \mathrm{C}$ & $100(8)$ & $\underset{(8)}{19.9 \pm 8.6}$ & $100(10)$ & $\begin{array}{c}21.4 \pm 20.8 \\
(10)\end{array}$ \\
\hline Collected and tested in January; $24.0^{\circ} \mathrm{C}$ & $100(9)$ & $11.1 \pm 3.5$ & $100(16)$ & $\underset{(16)}{11.2 \pm} 2.3$ \\
\hline Collected and tested in April; $21.1^{\circ} \mathrm{C}$ & $83(6)$ & $\frac{13.2 \pm 3.3}{(6)}$ & $100(5)$ & $11.6 \pm \frac{ \pm}{(5)} 1.1$ \\
\hline Collected and tested in April; $24.0^{\circ} \mathrm{C}$ & $100(6)$ & $8.0 \pm 1.4$ & $100(5)$ & $9.0 \pm \frac{ \pm}{(5)} 0.7$ \\
\hline
\end{tabular}

a Preoviposition period is mean \pm SD days; number of females is in parentheses.

Variation in the duration of diapause under all conditions was high throughout the overwintering seasons. This is evident in the wide range of preoviposition periods (Tables 1 and 2).

Diapause Maintenance-Riverhead (19821983 and 1983-1984). (Tables 3 and 4). In August and September, the incidence of oviposition was very low under short daylengths and the preoviposition periods were very long (Tables 3 and 4). During October, there was a slight increase in percentage oviposition; long daylengths and high temperatures shortened the preoviposition period.

During November and December, temperature did not have a major influence on the incidence of oviposition at long daylengths, but it did influence

Table 7. Summary of L. decemlineata emergence after overwintering at two localities in New York

\begin{tabular}{|c|c|c|c|c|c|}
\hline & \multicolumn{5}{|c|}{$\%$ emergence } \\
\hline & 1 & 10 & 50 & 90 & 99 \\
\hline \multicolumn{6}{|l|}{ Freeville } \\
\hline \multicolumn{6}{|l|}{1983} \\
\hline $\begin{array}{l}\operatorname{HDD}_{12^{a}} \\
\text { Julian date }^{b} \\
n=90\end{array}$ & $\begin{array}{r}84 \\
145\end{array}$ & $\begin{array}{l}148 \\
158\end{array}$ & $\begin{array}{l}227 \\
166\end{array}$ & $\begin{array}{l}404 \\
178\end{array}$ & $\begin{array}{l}447 \\
182\end{array}$ \\
\hline \multicolumn{6}{|l|}{1984} \\
\hline $\begin{array}{l}\mathrm{HDD}_{12^{a}} \\
\text { Julian date }^{b} \\
n=29\end{array}$ & $\begin{array}{l}160 \\
161\end{array}$ & $\begin{array}{l}241 \\
168\end{array}$ & $\begin{array}{l}278 \\
171\end{array}$ & $\begin{array}{l}406 \\
184\end{array}$ & $\begin{array}{l}507 \\
194\end{array}$ \\
\hline \multicolumn{6}{|l|}{ Riverhead } \\
\hline \multicolumn{6}{|l|}{1984} \\
\hline $\begin{array}{l}\mathrm{HDD}_{12^{a}} \\
\text { Julian date } \\
n=86\end{array}$ & $\begin{array}{r}1 \\
120\end{array}$ & $\begin{array}{r}1 \\
126\end{array}$ & $\begin{array}{r}4 \\
136\end{array}$ & $\begin{array}{r}19 \\
147\end{array}$ & $\begin{array}{r}30 \\
156\end{array}$ \\
\hline \multicolumn{6}{|l|}{1985} \\
\hline $\begin{array}{l}\operatorname{HDD}_{12^{a}} \\
\text { Julian date }^{b} \\
n=1,037\end{array}$ & $\begin{array}{r}6 \\
112\end{array}$ & $\begin{array}{r}24 \\
121\end{array}$ & $\begin{array}{r}37 \\
131\end{array}$ & $\begin{array}{r}96 \\
145\end{array}$ & $\begin{array}{l}161 \\
158\end{array}$ \\
\hline
\end{tabular}

${ }^{a}$ Heat-degree days 12 are based on soil temperatures at $15 \mathrm{~cm}$ (Riverhead) and $12 \mathrm{~cm}$ (Freeville).

${ }^{b}$ Julian date $145=25$ May $1983,161=9$ June $1984,120=29$ April 1984, $112=22$ April 1985 . influence the preoviposition period. Daylength influenced the incidence and the duration of the preoviposition period at all temperatures.

As the season progressed from January through March, the duration of the preoviposition period decreased under all conditions (with a few exceptions). Short daylengths, especially at the low temperatures, tended to decrease the incidence of preoviposition and increase the time for first oviposition.

By April, a high percentage of the beetles in all conditions oviposited, and the duration of the preoviposition period generally was inversely related to temperature. Under all conditions, variation in the duration of diapause was high throughout the overwintering period. Even in the April samples, a few beetles exhibited very long preoviposition periods under warm, long-day conditions (Tables 3 and 4).

Postdormancy Reproduction. In artificially overwintered beetles, the duration of the preovi-

Table 8. Reproductive responses to $L$. decemlineata females from Freeville, N.Y., to photoperiod and temperature during spring and summer

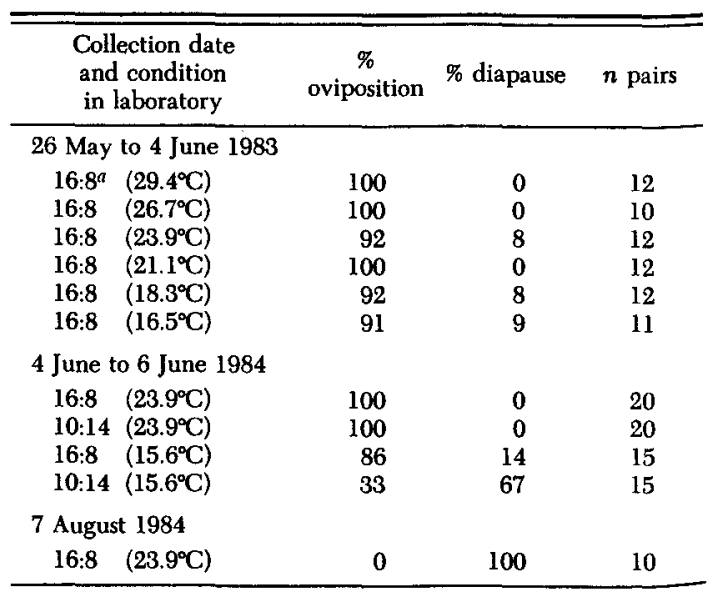

a Photoperiod (L:D). 


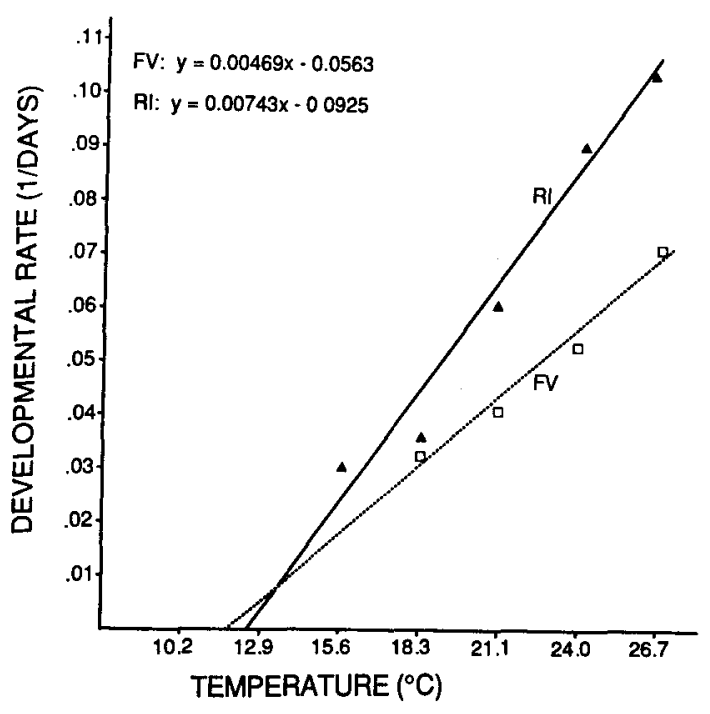

Fig. 1. Thermal requirements for oviposition by overwintered $L$. decemlineat a adults (16:8 photoperiod). $\mathrm{FV}=$ Freeville, N.Y., $t=12^{\circ} \mathrm{C}, K=213$ HDD; RI $=$ Riverhead, Long Island, N.Y., $t=12.5^{\circ} \mathrm{C}, K=134 \mathrm{HDD}$.

position period decreased with increasing temperatures (Table 5). Daylength did not influence the duration of the preoviposition period (Student's $t$ test: Freeville, $21^{\circ} \mathrm{C}: t=1.14, P=0.27 ; 24^{\circ} \mathrm{C}: t=$ 1.13, $P=0.27$; Riverhead, $21.1^{\circ} \mathrm{C}: t=0.92, P=$ 0.38 ).

The rate of reproductive development (one per preoviposition period) in females from Freeville and Riverhead increased linearly with increasing temperature (Fig. 1). The thermal thresholds for reproductive development were similar in the two populations (Freeville, $t=12.0^{\circ} \mathrm{C}$ and Riverhead, $t=12.5^{\circ} \mathrm{C}$ ); however, the number of heat-degree days $(K)$ required for oviposition differed markedly (Freeville: $K=213$ HDD and Riverhead: $K=135$ HDD).

Overwintered females that were isolated from males oviposited fertile eggs as frequently and within similar preoviposition periods as did paired fermales (Table 6). This was true whether the females were overwintered under laboratory or field conditions (Freeville, $t=-1.435, \mathrm{df}=17$ ) (Riverhead, January, $24^{\circ} \mathrm{C}, t=-0.067, \mathrm{df}=23$; April, $24^{\circ} \mathrm{C}, t=-1.394, \mathrm{df}=7$; January, $21.1^{\circ} \mathrm{C}, t=$ $-0.194, \mathrm{df}=16$; April, 21.1 ${ }^{\circ} \mathrm{C}, t=1.000, \mathrm{df}=9$ )

Postdiapause Emergence Under Field Conditions. At Freeville, overwintered beetles began postdiapause emergence on $25 \mathrm{May}$ in 1983 and on 9 June in 1984, and median emergence occurred after 227 and $278 \mathrm{HDD}_{12}$ had accumulated (soil temperature at $12 \mathrm{~cm}$ ). In both years, emergence extended approximately $35 \mathrm{~d}$. The range of heat accumulation over which 10-90\% emergence occurred was $256 \mathrm{HDD}_{12}$ in 1983 and $165 \mathrm{HDD}_{12}$ in 1984 (Table 7).

Beetles emerged much earlier (in calendar date and in physiological time) at Riverhead than Free- ville (Table 7). Emergence began on 29 April in 1984 and on 22 April in 1985 at Riverhead, and it required only 4 and $37 \mathrm{HDD}_{12}$ (soil temperature at $15 \mathrm{~cm}$ ) for median emergence. Emergence at Riverhead extended over about 36-46 d, but the period covering 10-90\% emergence involved a much smaller range of $\mathrm{HDD}_{12}$ (18 in 1984 and 72 in 1985) than at Freeville.

Ecophysiological Responses of Overwintered Beetles. Naturally overwintered and emerged beetles generally had a high incidence of oviposition under conditions of long daylengths (16:8 photoperiod) and high or low temperatures $\left(15.6-29.4^{\circ} \mathrm{C}\right)$. Under short daylengths, the incidence of oviposition was substantial only at high $\left(23.9^{\circ} \mathrm{C}\right)$ temperatures (Table 8). However, the incidence of oviposition was greatly reduced when overwintered beetles were exposed to short daylengths and low temperature $\left(15.6^{\circ} \mathrm{C}\right)$. Field-collected beetles from the first summer generation all entered diapause under long daylength and high temperature.

\section{Discussion}

Leptinotarsa decemlineata have a very intense diapause (as measured by the duration of the preoviposition period) in mid-August. At this time, diapause is only slightly affected by either photoperiod or temperature (Table 2). By mid-September, diapause intensity diminishes greatly, and photoperiod and temperature interact to maintain diapause (Tables 1 and 2). The intensity of diapause continues to decrease at a high rate until the end of October; subsequently, the relatively constant preoviposition period indicated that the rate of decline in diapause intensity is considerably slower. At high temperatures, responsiveness to photoperiod disappears by February; i.e., the percentage of oviposition and the time to oviposition at $23.9^{\circ} \mathrm{C}$ are similar across all photoperiods. However, the beetles remain responsive to photoperiod at low temperatures throughout dormancy (Tables 1, 2, and 8 ).

Our results indicate that most females enter dormancy after mating and are able to initiate fertile oviposition without mating again in spring (Table 6). This is consistent with previous reports (Minder \& Kozarzhevskaya 1966).

Unlike many insects studied (Tauber \& Tauber 1976), the Colorado potato beetle does not have a discrete break between the diapause and postdiapause periods. The intensity of diapause and the responses to photoperiod and temperature gradually change as the overwintering period progresses, but overwintered beetles continue to respond to photoperiod at low temperatures even after emergence (Table 8). This agrees with the findings of de Wilde and his coworkers that diapausing and nondiapausing Colorado potato beetles require longday conditions to sustain oviposition (see de Kort et al. 1980). It also agrees with previous work indicating that imaginal diapause in some species, 
including the Colorado potato beetle, is not an allor-none, but a graded response (Tauber \& Tauber 1976, Hodek 1983). In L. decemlineata sensitivity to photoperiod does not appear to be lost, but the range of temperatures over which it is expressed becomes restricted (Tables 1-4).

Overall, the seasonal progression of diapause in beetles from Freeville and Riverhead was similar (compare Tables 1 and 2 with 3 and 4). The primary difference between the two populations lies in the intensity (duration) of diapause. Because our samples at Riverhead did not begin until late $\mathrm{Au}$ gust, we do not know how intense diapause was before this time. However, in subsequent samples, beetles from Riverhead generally showed a much shorter preoviposition period (less intense diapause) than those from Freeville.

The two populations from New York also differed in their postdormancy thermal requirements for reproduction (Table 5; Fig. 1). The pattern of the variation is rare, but not unknown among insects studied to date (see Tauber et al. 1987). The two populations had equivalent thermal thresholds $\left(t=\sim 12^{\circ} \mathrm{C}\right)$ for reproductive development, but the Freeville population required $60 \%$ more heat-degree days for oviposition $\left(\mathrm{HDD}_{12}=213\right.$ for Freeville and 135 for Riverhead). A similar type of variation (approximately equal $t$ values and large differences in $K$ values) was found for postdiapause development by Ostrinia nubilalis Hübner from two climatically different areas of Alberta, Canada (Lee \& Spence 1987). Just as with the Colorado potato beetle, heat requirements for completion of development were lower for the $O$. nubilalis population associated with the milder climate.

The differences in ecophysiological responses (depth of diapause and thermal requirements for development after dormancy) between the two populations were reflected in their patterns of emergence in the field. At Riverhead, median emergence occurred much earlier (in calendar date and physiological time) than at Freeville-after only 4 (1984) and 37 (1985) $\mathrm{HDD}_{12}$ had accumulated, in comparison with the 227 (1983) and 278 (1984) $\mathrm{HDD}_{12}$ for median emergence at Freeville (Table 7). It is important to recognize this type of interpopulation variation and to include it in phenological models designed to predict emergence. Because of the intrinsic differences that can occur among geographic populations, a model that accurately predicts emergence by overwintered beetles in New Jersey (Lashomb et al. 1984) does not describe emergence at either Freeville or Riverhead.

The L. decemlineata from Riverhead presented us with an intriguing anomaly. Females that had overwintered in the laboratory required approximately $135 \mathrm{HDD}_{12}$ to emerge from the substrate (vermiculite) and to initiate oviposition. In contrast, median emergence in the field required only 4 (1984) and 37 (1985) HDD 12 . The thermal responses and behavior of beetles in the soil may vary as the overwintering period progresses (Minder \& Kozarzhevskaya 1966). Either of these, or other, factors could have caused the discrepancies between predicted and actual times of emergence.

Adaptive Significance. The patterns of response we obtained are in keeping with two important aspects of the phenology of the Colorado potato beetle. First, the critical photoperiod for diapause induction, the thermal requirements for nondiapause reproduction, the thermal influence on diapause induction, the intensity of diapause, and the thermal requirements for postdormancy oviposition vary between the two populations in New York state, in what appears to be an adaptive manner (C. A. Tauber et al. 1988, M. J. Tauber et al. 1988). Mild temperatures and sandy soil allow early planting of potatoes at the coastal (Riverhead) site; this favors early emergence and a high incidence of bivoltinism in the Colorado potato beetle. In turn, these traits may result in selection for a less intense diapause and reduced thermal requirements for reproduction, both after dormancy and during the summer (C. A. Tauber et al. 1988, M. J. Tauber et al. 1988).

At the cooler, inland site (Freeville), where the soils are heavy and moisture-laden, and potatoes are planted one month later than on Long Island, the situation is reversed. Spring emergence occurs late, and there is a high incidence of univoltinism. These traits favor an intense diapause and high thermal requirements for reproduction in both overwintered and summer beetles.

Second, intrapopulation variability plays an important role in the phenological adaptation of the beetle. This is true for the induction of diapause during the summer (C. A. Tauber et al. 1988, M. J. Tauber et al. 1988), and it also holds for overwintered beetles. The beetles have considerable intrapopulation variation in their patterns of spring emergence (Table 7), and in the physiological responses that control emergence. Diapause intensity and the thermal requirements for oviposition are very variable among individuals (i.e., range of variation on Tables 1-5). In addition, there are geographical differences in the variability in the physiological responses. The approximately $35-\mathrm{d}$ spread in vernal emergence at Freeville occurs over a range of 165 to $256 \mathrm{HDD}_{12}$; at Riverhead a larger spread in emergence time (36-46 d) is achieved within a range of only 18 to $72 \mathrm{HDD}_{12}$. Thus, it appears that selection acts not only on the timing of emergence after dormancy, but also on the variability in the response patterns that control the range of variation in emergence.

\section{Acknowledgment}

We thank W. M. Tingey, Cornell University, for his cooperation. Some of the laboratory data from the Long Island population are based on a M.S. thesis conducted in our laboratory by D. M. Lansky (1984). The work was carried out in conjunction with regional cooperative proj- 
ect NE 154 and supported in part, by USDA Competitive Grants (\#87-CRCR-1-2376 and \#7800454 and subsequent renewals). We acknowledge CALS IPM Program and the Office of Research, Cornell University Agricultural Experiment Station, which also provided partial support.

\section{References Cited}

Arnoldi, K. V. [ed.]. 1966. Ecology and physiology of diapause in the Colorado beetle. Iz'datel'stvo "Nauka," Moscow (English translation, Indian National Documentation Centre, New Delhi, 1976).

Briers, T., M. Peferoen \& A. de Loff. 1982. Ecdysteroids and adult diapause in the Colorado potato beetle, Leptinotarsa decemlineata. Physiol. Entomol. 7: 379-386.

de Kort, C. A. D. 1981. Hormonal and metabolic regulation of adult diapause in the Colorado beetle, Leptinotarsa decemlineata (Coleoptera: Chrysomelidae). Entomol. Gen. 7: 261-271.

de Kort, C. A. D., H. Schooneveld \& J. de Wilde. 1980. Endocrine regulation of seasonal states in the Colorado potato beetle, Leptinotarsa decemlineata, pp. 233-240. In A. K. Minks \& P. Gruys [eds.], Integrated control of insect pests in the Netherlands. Wageningen Cent. Agr. Publ. Documentation, Wageningen, The Netherlands.

de Wilde, J. \& T. Hsiao. 1981. Geographic diversity of the Colorado potato beetle and its infestation in Eurasia, pp. 47-68. In J. H. Lashomb \& R. Casagrande [eds.], Advances in potato pest management. Hutchinson Ross, Stroudsburg, $\mathrm{Pa}$.

Hodek, I. 1983. Role of environmental factors and endogenous mechanisms in the seasonality of reproduction in insects diapausing as adults, pp. 9-33. In V. K. Brown \& I. Hodek [eds.], Diapause and life cycle strategies in insects. Junk, The Hague.

Hsiao, T. 1981. Ecophysiological adaptations among geographic populations of the Colorado potato beetle in North America, pp. 69-85. In J. H. Lashomb \& R. Casagrande [eds.], Advances in potato pest management. Hutchinson Ross, Stroudsburg, $\mathbf{P a}$.

Lansky, D. W. 1984. Phenology of the Colorado potato beetle (Leptinotarsa decemlineata) population on Long Island: prediapause development and hibernation. M.S. thesis, Cornell University, Ithaca, N.Y.

Lashomb, J. H., Y.-S. Ng, G. Ghidiu \& E. Green. 1984.
Description of spring emergence by the Colorado potato beetle, Leptinotarsa decemlineata (Say) (Coleoptera: Chrysomelidae), in New Jersey. Environ. Entomol. 13: 907-910.

Lee, D. A. \& J. R. Spence. 1987. Developmental adaptation of the European corn borer (Ostrinia nubilalis Hübner) in Alberta. Can. Entomol. 119: 371380.

Minder, I. F. \& E. F. Kozarzhevskaya. 1966. Ecology of winter diapause of Colorado beetle, pp. 59-93. In K. V. Arnoldi [ed.], Ecology and physiology of diapause in the Colorado beetle, Iz'datel'stvo "Nauka," Moscow (English translation, Indian National Documentation Centre, New Delhi, 1976).

Stearns, S. C. 1983. Introduction to the symposium: the interface of life-history evolution, whole-organism ontogeny, and quantitative genetics. Am. Zool. 23: 3-4.

Tauber, C. A. \& M. J. Tauber. 1986. Ecophysiological responses in life-history evolution: evidence for their importance in a geographically widespread insect species complex. Can. J. Zool. 64: 875-884.

Tauber, C. A., M. J. Tauber \& J. H. Nechols. 1987. Thermal requirements for development in Chrysopa oculata: a geographically stable trait. Ecology 68: 1479-1487.

Tauber, C. A., M. J. Tauber, B. Gollands, R. J. Wright \& J. J. Obrycki. 1988. Preimaginal development and reproductive responses to temperature in two populations of the Colorado potato beetle (Coleoptera: Chrysomelidae). Ann. Entomol. Soc. Am. 81: $755-763$.

Tauber, M. J. \& C. A. Tauber. 1976. Insect seasonality: diapause maintenance, termination, and postdiapause development. Annu. Rev. Entomol. 21: 81107.

Tauber, M. J., C. A. Tauber \& S. Masaki. 1986. Seasonal adaptations in insects. Oxford Univ. Press, New York.

Tauber, M. J., C. A. Tauber, J. J. Obrycki, B. Gollands \& R. J. Wright. 1988. Voltinism and the induction of aestival diapause in the Colorado potato beetle, Leptizotarsa decemlineata (Coleoptera: Chrysomelidae). Ann. Entomol. Soc. Am. 81: 748-754.

Received for publication 11 November 1987; accepted 27 April 1988. 